\title{
THE GENERAL CEILING PRICE REGULATION- PROBLEMS OF COVERAGE AND EXCLUSION ${ }^{\dagger}$
}

\author{
Alfred Letzier* \\ I \\ Development and Structure of the Regulation
}

\section{A. Introduction}

Direct price controls under OPS really began when the General Ceiling Price Regulation (GCPR) was issued on January 26 , $195{ }^{1 .}{ }^{1}$ Although described as an interim regulation, the GCPR remained in effect for many sellers and commodities throughout the entire period of price control from January 195I to March 1953. In this respect, it paralleled the history of its predecessor under the Office of Price Administration during World War II, the General Maximum Price Regulation (GMPR or General Max), after which it was largely patterned.

Each of these two general price freeze regulations was issued after an initial period in which reliance was placed mainly on voluntary or selective techniques of price control, and only after the stabilization agencies became convinced that such voluntary or selective methods would not work. ${ }^{2}$ Based on past experience, it seems reasonable to expect that, in a future general emergency calling for the imposition of direct price controls, a general price freeze will be utilized again.

The purposes of this study are to describe the origin and development of some of the major provisions of the GCPR and to analyze and discuss some of the problems not apparent from a mere reading of the regulatory provisions themselves, and in doing so to set down some comments and suggestions which might be of value in connection with the use of a general freeze in the future.

The factors that led to the use of other methods of price control for many things originally covered by the general freeze, are beyond the scope of this study. Under both OPA and OPS, a general freeze was viewed primarily as a comprehensive stopgap measure, and secondarily as a continuing mechanism for miscellaneous items. Some of these were not sufficiently important or troublesome to require specific regulations; for others, the freeze was as good a technique of control as any other.

tThe opinions herein expressed are the author's and do not necessarily reflect the position of any past or present Government agency.

*A.B. 1931, Cornell University; LL.B. 1933, Columbia University Law School. Attorncy with Securities and Exchange Commission. Formerly Associate Chief Counsel, Office of Price Stabilization, and Assistant General Counsel, Office of Price Administration. Author, Price-Supply Problems in Building Materials, chapter 19 in Problems in Price Control: Changing Production Patterns, Gen. Pur. No. 9, OPA Historical Reports on War Administratton 293-357 (1947). Contributor of articles to Columbia Law Review.

${ }^{1}$ I 6 FED. REg. 808 (I95I).

${ }^{2}$ However, prior to the issuance of the GMPR OPA had issued more than one hundred specific regulations, whereas OPS had issued only two prior to the GCPR, one of them issued only the day before. 
The major defects of a general freeze appear when it is viewed as a long-run comprehensive control method. Any attempt to analyze the inherent limitations that made it desirable to replace the general freeze in particular cases would encompass the whole range of problems and activities of the price stabilization program.

This study, then, is more in the nature of an exposition of the technical problems of a general price freeze, using the actual experience under the GCPR as the vehicle. It, therefore, seeks to discuss only the regulatory and interpretative problems to be faced once those in policy-making positions have decided upon a general price freeze.

While some problems cannot be known in advance of the actual occasion for the imposition of a freeze, many aspects of a general price freeze would be much the same under almost any circumstances, and were much the same during the time of both OPA and OPS. A description of the provisions of the GCPR, and an analysis of some of the most vexing problems, therefore, can be useful for the future.

The basic framework of the GCPR, like that of the GMPR, is fairly well known. In brief, the general freeze covered most sales of commodities and services, and fixed each individual seller's ceilings at the highest prices he himself charged during a preceding base period. The primary and immediate purpose of the general freeze was to stop the upward thrust of all price movements, and to give the stabilization agency time to issue tailored regulations for specific industries.

The freeze technique catches business and prices as of a specific period in time. But the business conditions themselves do not remain frozen. A "pure" freeze does not provide for people not in business, or for commodities not sold, during the base period. So other methods in addition to the pure freeze had to be devised to take care of the problems of new goods and new sellers. These included the techniques of formula, comparison, and competitive pricing, and each raised its own series of complex administrative and interpretative problems.

In addition, the GCPR was not literally and completely a "general" freeze. It covered most, but not all sales of commodities and services. Some of the exceptions were based on statutory exemptions or limitations, others on grounds of administrative difficulties, and others on overriding considerations such as the needs of the defense program.

The advantage of a general freeze is that it can be issued quickly to cover immediately a wide area. A large staff is not essential to its issuance, since it is based primarily on existing prices and practices, and requires a minimum of factual investigation and information. By the same token, the very comprehensiveness of a general freeze would require a large staff either to administer it if it is to remain in effect for any significant period of time as a continuing mechanism of control, or to replace it with more specific regulations under a continuing program of price control. An adequate staff is necessary to authorize exceptions and adjustments to avoid serious hardship, impairment of the defense program, or general disregard of the regulation.

The effects of a general freeze on some individual sellers or industries might 
become intolerable even over a short period of 60 or 90 days. On the other hand, many problems, even though serious to the persons involved, can be "lived with" for a short time, if there is some assurance that help is on the way. For the short term, therefore, a general freeze need not "fit" perfectly for everybody-this, as already indicated, both facilitates its issuance and complicates its administration or replacement.

Even for the short term, however, the specific provisions of a general freeze may serve to ease the administrative burdens. Some of the later refinements of the GCPR, if included at the outset in any future general freeze, might eliminate some of the pressure on the administrative staff. This would leave the staff to that extent freer to cope with the many problems that cannot be eliminated except by the issuance of specific regulations to replace the freeze.

For example, a more liberal exemption policy for small business, for insignificant items difficult to control, and for other situations where exemptions would have no real impact on the stabilization program, and the earlier use of "built-in" adjustment provisions (like the one permitting the use of price lists where some-but not all-of the items had been sold at the list prices during the base period) would have made it unnecessary for large numbers of sellers to come to OPS for information or relief. At the same time, the resulting "relaxation" would not have been expensive to the stabilization program, certainly not in relation to the time and effort required to listen to, much less answer, the complaints and pleas otherwise encountered.

\section{B. Selection of the Base Period}

The GCPR, issued on January 26, 1951, established ceilings on the basis of prices in effect during the base period of December 19 , 1950 to January 25, 1951, inclusive. The GMPR, issued by OPA on April 28, 1942, used the month of March 1942 as a base period.

Both freezes used base periods later than those mentioned in the respective statutes. The Emergency Price Control Act of $1942^{2^{a}}$ directed that so far as practicable consideration be given, among other things, to the prices prevailing between October I and October 15, 1941. Similarly, the Defense Production Act of $1950^{2 b}$ referred to prices prevailing May 24, I950 to June 24, I950, inclusive, the month prior to the Korean invasion.

Selection of a base period posed three main questions: (I) How far back should the base period be set-in other words, how much of a rollback of prices, if any, should be required; (2) how long should the base period be-a day, week, month, or longer; and (3) should there be a uniform base period for all sellers or staggered base periods for different groups or levels?

The Defense Production Act itself contained no provision regarding a base period for a freeze, other than the direction that so far as practicable consideration be given, among other things, to the level of prices prevailing May 24 to June 24, I950.

22 56 StaT. 23, 24 (1942), as amended, 50 U. S. C. App. \$\$90I, 902(a) (I946).

${ }^{2 b} 64$ STAT. 798, 803 (1950), as amended, 50 U. S. C. App. $\$ \$ 2061,2102$ (b)(c) (Supp. 1952). 
In January 1951, a rollback to the prices in effect during the period May 24 to June 24 , $195^{\circ}$ seemed clearly out of the question. The situation was complicated, however, by the fact that the Economic Stabilization Agency's public announcement on December I9, I950 of its Voluntary Pricing Standards included the following sentence:

The Agency served notice upon all sellers affected by the standards that any official price action hereafter taken will make use of a base period ending not later than December $\mathrm{x}, 1950$, and that no seller will derive any advantage under the regulations from price increases after that date.

The longer the issuance of a general freeze was delayed, the more difficult it was to restore pre-December $195^{\circ}$ prices. In late January I95I, a rollback to December I, I950 price levels would have meant approximately a two-month rollback, as compared with just under a month by OPA. There were strong practical arguments against such a rollback. It was not possible to roll back wages, representing an important element of business costs, and, of course, under the Defense Production Act the imposition of wage controls was tied to price controls. Neither could the prices of many imported commodities, some of which represented important costs to domestic manufacturers and processors, be rolled back. Furthermore, farm products generally were below the statutory minimum prices, and OPS was legally unable even to fix ceilings on many agricultural commodities, much less roll back their prices.

It was reluctantly concluded that any significant rollback was not feasible. Reluctantly, for two reasons: First, the decision meant that the freeze would catch prices at a higher level during a period in which cost-price relationships were more distorted; second, it appeared to be a breach of faith with those who had relied on the statement that no seller would derive any advantage under price regulations from price increases made after December I, 1950 .

OPS believed that any base period would provide serious problems, but that one as near in time as possible to the date of the freeze would provide the fewest administrative difficulties. ${ }^{3}$ The Statement of Considerations for the GCPR recognized the practical considerations, and sought to mollify the reaction to the current freeze by stating that in the future the price-cost structures in the various industries would be examined to determine where changes in existing prices were appropriate.

It had been proposed that the base period end on January 19, 195I, to avoid legalizing price increases after that date in anticipation of the freeze. A modest rollback of this kind to cut off last minute price increases seemed both feasible and desirable. The proposal was rejected, however, in part because of the opposition to any rollback, and in part because of the decision to make the freeze effective immediately upon issuance on January 26 , $195{ }^{4} .^{4}$ Had the original plan to make the

\footnotetext{
${ }^{3}$ Memorandum from Michael V. DiSalle to Eric Johnston, Jan. 20, 195r. This had also been the OPA view. See the Statement of Considerations for the GMPR.

- For a more detailed discussion of the events leading up to the decision to use a current base period and make the regulation effective immediately, see Gardner Ackley, Selected Problems of Price Control Strategy, I950-I952 (unpublished OPS study) c. 2.
} 
freeze effective two weeks after issuance been followed, sellers would have had time to adjust their prices under a rollback; to make a rollback effective immediately would undoubtedly have caused numerous sellers to be in violation of the regulation. ${ }^{5}$

The length of the base period was not as controversial as the question of a rollback. OPA had used a calendar month as the base period. OPS used a period of approximately five weeks. Generally, in both instances, the objective was to select the shortest period that would catch representative transactions for the bulk of the volume of sales. For such a comprehensive regulation as the GCPR or the GMPR, it was felt that a base period of at least one month was required to achieve this objective.

If a base period is made too short, it is not likely to cover enough sales to be representative, especially for items with a long production period. If a long base period is used, more sellers are covered, but then there is the danger that going back too far will freeze many sellers at out-of-line prices.?

When the same base period is used for all sellers, inequities may result from the fact that some sellers have not had or used the opportunity to raise prices as fast as others. A uniform base period thus could freeze many sellers' costs at a high level and their selling prices at a lower level. For this reason, both in OPA and OPS the use of staggered base periods was considered, but eventually rejected because of the complexity of the problems involved.

Inequities resulting from the use of a uniform base period could be most serious at the distributive levels. In many industries, price increases at the manufacturing level normally would be reflected sometime later at the wholesale level, and yet later at the retail level. But this was not uniformly so, and also the period before the imposition of the freeze was not a normal period in the usual sense.

The use of staggered base periods would have required a determination of what were reasonable lags for wholesalers or retailers. Furthermore, many manufacturers' prices also lagged behind increases in their costs. OPS concluded that the use of one base period for all sellers, with a recognition that inequities existed which would be adjusted as soon as they could be identified, would be easier to justify than the use of questionable time lags from the start. ${ }^{8}$

The Statement of Considerations for the GCPR also cast some doubt on the seriousness of the lag problem: ${ }^{2}$

\footnotetext{
'Under OPA, the GMPR became effective for manufacturers on May II, 1942, two weeks aftcr issuance, and for retailers on May 18, 1942, three weeks after issuance.

${ }^{\circ}$ For OPA practice, see Dickerson, The Indzistry Earnings Standard, in Problems in Price Contros: Pricing Standards, Gen. Pub. No. 7, OPA Historical Reports on War Administration 27, at 69 (1947).

${ }^{7}$ For example, if a base period of six months were used, and a seller's only salc of a particular commodity came on the first day of that period, he would be frozen to that six months' old price. In the same situation but with a one-month base period, his price for that particular commodity would be fixed in line with prices charged for other commodities in the one-month period.

${ }^{8}$ Memorandum of Jan. 20, 195I, from Michael V. DiSalle to Eric Johnston.

${ }^{\circ}$ In reaching this conclusion, OPS may have been influenced by the feeling that the OPA expericnce with GMPR indicated the importance of the squeeze problem was probably overestimated. See Hart,
} 
The base period selected is uniform for all sellers covered by this regulation. Normally, there is a lag between a change in prices at one level and a corresponding change in prices at the next level of production and distribution. The degree of the lag usually depends on the rapidity with which merchandise is turned over and on the state of the markets. But these are certainly not normal times. The speed with which prices have been rising over the whole economy indicates that most sellers have been keeping pace with, and in many cases anticipating, the rise in costs.

Undoubtedly the selection of the base period may minimize or complicate the administrative problems of a general freeze. Yet attempts to minimize the administrative problems by selecting an earlier base period to freeze a lower level of prices and a better price relationship, or by using staggered base periods for the different levels of production and distribution, might have created worse administrative problems than those sought to be thus avoided. ${ }^{10}$

Although failure to provide for a rollback in setting the base period for the GCPR has been criticized as a mistake, the substance of that criticism is really directed at the failure to issue the regulation earlier. Failure to act earlier admittedly posed serious problems in the administration of the stabilization program. But having failed to act earlier, it is doubtful if the Government could have simplified those problems by seeking to turn back the clock to pre-December I950 prices. ${ }^{11}$

The major lesson seems to be that it is better and easier to catch the price structure at a reasonable stage before it gets out of hand, rather than to let it get out of hand and then seek to restore it to some prior "normalcy." Congressional and business sentiments were much stronger against rollbacks than they were against an earlier imposition of a freeze. OPS's subsequent unhappy experience with rollback attempts was evidence of this although it must be recognized, of course, that the earlier a rollback is attempted the greater are its chances of success.

The Genetal Maximum Price Regulation, in Problems in Price Control; Pricing Techniques, Gen. Pub. No. 8, OPA Historical Reports on War Administration I, i2 (1947).

${ }^{10} \mathrm{It}$ is interesting to note the base period provisions in S. 108I and H. R. 3184, 83rd Cong., Ist Sess. (1953), bills introduced in February, 1953, by Senator Capehart and Representatve Multer, respectively, to give the President standby authority to issue a 90-day freeze in an emergency. The Capehart bill, as passed by the Senate on May 19, 1953, authorized the establishment of ceilings on prices "at those prevailing as of the close of business on the business day next preceding the day on which the action is taken, or those prevailing on the nearest date during the preceding thirty days on which, in the judgment of the President, they are generally representative, or if none prevailed during such thirty day period, then those prevailing on the nearest date on which, in the judgment of the President, they are generally representative." The Multer bill authorized a freeze as of a "base date or dates, or base period, not more than one month prior to such order."

Both bills thus seemed to prohibit a rollback of more than a month. S. 753, a bill introduced earlier in February, 1953, by Senator Capehart to give the President general standby authority for economic controls, seemed (Sec. 402) to prohibit any freeze rollback by requiring that the initial fixing of ceilings be "at the level prevailing as of the close of business on the business day next preceding the day on which the action is taken."

iI The General Manufacturers' Regulation, CPR 22, I6 FED. Reg. 3562 (x95I), only attempted to restore approximately the price levels of Dec. 3I, I950. But while CPR 22 provided that pre-Korean prices could be increased to reflect increases in cost of many manufacturing materials only up to Dec. 3I, I950, many other raw materials cost increases were allowed up to March I5, x95x. Furthermore, cost increases for farm commodities below parity were allowed up to any current date. And for labor, cost increases could also be computed up to March 15, 195I. These provisions recognized the impracticability of rolling back prices in certain areas of the economy. 
A modest rollback period, of approximately two to three weeks, undoubtedly would have been feasible, and would have minimized to some extent the distortions otherwise frozen into the price structure. Whether it would have made enough difference to have had a significant effect on the stabilization program is problematical. It would have required postponement of the effective date of the freeze for at least two weeks, and after having delayed so long, the stabilization agencies were anxious to make the freeze effective immediately and avoid possible confusion and uncertainty during a waiting period.

In retrospect, the use of a uniform current base period seems justified, certainly in the light of the objective of speedy and comprehensive control at one stroke. The lag in distributors' prices and other problems, could be, and were, met later by the issuance of specific regulations tailored for such problems.

\section{Coverage}

The Statement of Considerations for the GCPR stated:

The purpose of the accompanying general regulation is to hold prices on a broad front. Accordingly, it covers the widest possible range of commodities and sellers. Manufactures, wholesalers and retailers together with suppliers of services come within its terms. The intention has been to include within its scope all sellers of all commodities and services except to the extent that legal or strong practical reasons require that particular sellers or types of commodities be exempt.

The basic approach, dictated by the very concept of a "general" freeze, was that everything and everyone was covered, unless specifically excluded. Notwithstanding general agreement as to the approach on coverage, many problems, some of a technical nature, existed with respect to the definitions of commodities, services, persons, sales, the list of exemptions, the treatment of imported commodities, etc. These will be discussed below.

I. Definition of Commodities and Services. The GCPR defined commodities, in Section 22, as including "commodities, materials, articles, products, supplies, components processes. ..."12 This was almost verbatim the definition of "materials" in Section 702(b) of the Defense Production Act (50 U. S. C. App. \$2152(b) (Supp. 1952)).

The general term "commodities" was more a part of the folklore of OPS, as it was of OPA, than "materials." There is no evidence that the use of "materials" in the Defense Production Act was intended to have a different result than the use of "commodity" in the Emergency Price Control Act of 1942 . In fact, it was clear that "materials" was intended to be at least as comprehensive as "commodity" was under the Emergency Price Control Act; materials as defined in the Defense Production Act included "commodities."13

\footnotetext{
12 The definition originally also included "and contracts to buy, sell or deliver any of the forcgoing." These words, which also appeared in the definition of commodity in the GMPR, are not rcally necessary to the definition, and caused some persons to claim different ccilings for contracts as against deliveries. For this reason, they were deleted by Amendment 2 to the GCPR, I6 Fed. Reg. I789 (I95I).

13 "Commodity" as defined in Sec. $302(c)$ of the Emergency Price Control Act of 1942 also included "materials."
} 
Just as the definition of commodities was intended to include every tangible object not specifically excluded, so the definition of service was intended to include every operation or function other than that of an employee. ${ }^{14}$ Thus fees or charges for the granting of a privilege, for forbearance to act, and for rentals of commodities or services were subject to the regulation as prices for services.

The GCPR covered many services not subject to regulation by OPA. The Emergency Price Control Act had applied only to services supplied in connection with a commodity. ${ }^{15}$ This restriction did not appear in the Defense Production Act. Thus the Defense Production Act and the GCPR applied to many personal services unrelated to commodities, as for example, most banking services. ${ }^{\mathbf{1 6}}$

The GCPR became effective immediately for services as well as commodities. Under the GMPR, issued April 28, I942, the prohibition and maximum price provisions did not apply to sales of services at retail until July I, I942, and prior to that date, OPA issued a special regulation for services. ${ }^{17}$

OPS as soon as practicable also issued a specific regulation replacing the GCPR for most services. ${ }^{18}$ But while OPA had in effect exempted retail services pending the preparation of a services regulation, OPS covered services generally under the general freeze while it was readying its services regulation.

Recognizing that a general freeze cannot adequately meet the special needs of numerous suppliers of services, just as it cannot adequately meet the special needs of other industry groups, the purposes of a general freeze are better served by covering services for the short term while a specific regulation is being drafted, as OPS did, than by exempting them as OPA did. If retail sellers of services are to be exempt from a general freeze until a specific regulation can be worked out for them, why not retail sellers of commodities, or other special areas? This approach, carried far enough, turns a "general" freeze into a technique of selective controls, thus frustrating the very purpose of the general freeze-to cover quickly the broad front of commodities and services.

2. Persons and Transactions Covered. The regulation not only prohibited sales at prices exceeding the ceiling prices, but also prohibited any person from buying in the regular course of business or trade at a price higher than ceiling. The regulation defined "person" in the terms of Section 702(a ) of the Act (50 U. S. C. App.

14 Wages and salaries, while subject to control under the Defense Production Act, were under the jurisdiction of the Wage and Salary Stabilization Boards, and so were excluded from price regulations.

The definition of service in the GCPR also originally included a reference to contracts to sell or supply services. This was deleted by Amendment 2 to the GCPR, for the same reason as applied to the deletion of a similar reference to contracts in the definition of commodities.

10 Actually, Sec. 302(c) of the Emergency Price Control Act of 1942 defined commodity as including services rendered otherwise than as an employee in connection with the processing, distribution, storage, installation, repair or negotiation of sales of a commodity.

${ }^{10}$ One banking service that was subject to control under OPA was the rental of safe deposit boxes. It was held that the definition of commodity under the Emergency Price Control Act included the storage of jewelry and securities, and that this constituted a service in connection with the storage of commodities. See Lincoln Savings Bank v. Brown, 337 F. 2 d 228 (E.C.A. 1943).

${ }_{17}$ Maximum Price Regulation I65, 7 FEd. REG. 4734 (1942).

${ }^{18}$ CPR 34, I6 FED. REg. 4446 (1951). 
\$2152(a) (Supp. 1952)) to include an "individual, corporation, partnership, association, or any other organized group of persons, or legal successors or representative of the foregoing, and includes the United States or any agency thereof, or any other government, or any of its political subdivisions, or any agency of any of the foregoing."

Section 405 of the Defense Production Act (50 U. S. C. App. \$2105(a) (Supp. 1952)) made buyers' over-ceiling payments unlawful only when the buyer was buying or receiving any commodity or service in the regular course of business or trade. ${ }^{10}$ A purchase in the regular course of business or trade included one by an industrial, commercial or governmental consumer, or by a person in the business of buying for resale, but did not include purchases by individual ultimate consumers for their own or family use. Sellers, however, were subject to ceiling price restrictions whether or not their sales were made in the regular course of business or trade. ${ }^{20}$

Under the definition of person, the separate identity of a corporation was preserved, and transactions between corporations were subject to the ceiling price restrictions even when between affiliated corporations. In the absence of specific regulatory provisions, different corporate entities were regarded as different sellers except where necessary to prevent fraud. ${ }^{21}$ Although undoubtedly some transactions between affiliated companies might have been treated as bookeeping transactions similar to transactions between two divisions of one company, neither time nor staff permitted an examination of transactions of this kind to determine when an exemption from the general freeze would have been justified and when it would have been subject to abuses. In later months, it was possible to give attention to specific situations and to determine that no harm to the stabilization program would come if some inter-corporate transactions were exempt.

For example, sales of iron ore, bauxite, pulpwood, and tobacco between affiliated corporations were exempted by later actions. ${ }^{22}$ The statements of considerations indicated that although the affiliated corporations were technically separate persons under the definition in the GCPR, transactions between the affiliates in these cases were really similar to transfers betweens divisions or units of the same business. It is significant that these transactions involved raw materials, and it was found that the exemption of sales between affiliates would not affect ceilings on the finished products. A general exemption of transactions between affiliated corporations, however, would not seem desirable, and certainly not as a part of a general freeze.

The GCPR in general cut across pre-existing contracts, by making the prohibitions against over-ceiling transactions apply "regardless of any contract or other obliga-

${ }^{10}$ A similar restriction appeared in the Emergency Price Control Act of 1942, Sec. 4(a). The Capehart and Multer bills to give the President standby authority to impose a 90-day frecze also contained similar limitations (S. I08I and H. R. 3I84, 83rd Cong., Ist Sess. (1953)).

${ }^{20}$ Interpretations, OPS Loose Leaf Service, 42 Reg Ir:202.x.

${ }^{21}$ Interpretations, OPS Loose Leaf Service, $42 \operatorname{Reg}$ II:222.4I.

22 Amendment I6 to GOR 9, I7 FEd. Reg. 3648 (I952); Amendment 30 to GOR 9, 18 FED. REo. 227 (1953); Amendment 8 to GOR 8, I8 FED. REG. 824 (I953); Supplementary Regulations II9 to the GCPR, I7 FED. REG. 8346 (I952). 
tion." A similar provision had been included by OPA in the GMPR and had been held valid by the courts. ${ }^{23}$

Authority to cut across pre-existing contracts was contained in Section 402 (d) (I) of the Defense Production Act of r950 (50 U. S. C. App. \$2ro2(d) (x) (Supp. 1952)), which read:

Regulations and orders issued under this title shall apply regardless of any obligation heretofore or hereafter incurred except as provided in this subsection; but the President shall make appropriate provision to prevent hardships and inequities to sellers who have bona fide contracts in effect on the date of issuance of any such regulation or order for future delivery of materials in which seasonal demands or normal business practices require contracts for future delivery.

The GCPR made no provision for existing contracts to prevent hardship, because it was impossible to identify in advance the specific types of hardship situations which a general freeze might create and which would qualify for relief under this Section of the Act. ${ }^{24}$

Section ro(c) of the regulation did, however, permit importers of strategic materials to pass on price increases for imported goods received after January 26, I95I, pursuant to contracts entered into on or before that date. The purpose of this was to maintain essential supply, as well as to avoid the damage to our relations with friendly nations that would have resulted if importers canceled bona fide contracts. Once deliveries on existing contracts were disposed of, the importer's ceiling price reverted to the base level.

Soon after the issuance of the GCPR, a somewhat similar dispensation was given exporters, who were permitted to fulfill written contracts for export sales executed, or based upon firm.written orders made, prior to January 26 , $195^{1.25}$ The exporters were required, however, to observe the domestic ceilings on their purchases.

As justification for this action, it was stated that there is an extra time lag in the case of exports between the contract date and the date of delivery, because of the special factors applicable to export sales, special packing, shipping arrangements, license clearances, etc. Second, it was felt that the failure to fulfill contracts for export might have a detrimental effect on foreign trade, business reputation for honoring contracts, and foreign relations generally. Also, the relief thus granted exporters would not generally have any inflationary impact in the United States.

Any general exception of existing contracts would be inconsistent with the

${ }^{23}$ Seminole Rock and Sand Co. v. Fleming, 170 F. 2d 542 (E.C.A. 1947).

24 The general problems relating to adjustments under the freeze, to relieve hardship and for other purposes, are discussed in another study. Sec. 4 (a) of the Emergency Price Control Act of I942, the statutory authority for the provision in the GMPR cutting across existing contracts, did not require any special provision to prevent hardship for sellers who had contracts in effect when the regulation was issued. Nor did the Capehart and Multer bills to give the President standby authority to impose a 90-day freeze (S. I081 and H. R, 3I84, 83rd Cong., Ist Sess. (I953)) limit the authority to cut across existing contracts.

${ }^{25}$ SR 9 to the GCPR, I6 FED. REG. 2063 (I95I). Originally this was limited to merchant exporters who bought commodities for resale to foreign buyers. A revision, 16 FED. REc. 4I94 (195I), extended the application of the regulation to cover producer exporters as well. 
purposes and effectiveness of a general freeze. After a general freeze is issued, it may be possible and desirable, on analysis of specific situations, to authorize the carrying out of some pre-existing contracts. For example, at a later date, OPS permitted sellers of chemicals and certain other commodities under long-term contracts made prior to price control to apply for permission to carry out those contracts, even though this resulted in prices higher than the base period prices. ${ }^{26}$

3. Geographical Application and Treatment of Exports and Imports. The GCPR, like the GMPR, applied in the continental United States (the 48 states and the District of Columbia) and also to the territories and possessions. Nevertheless, it was recognized that the same freeze could not be long maintained for both the mainland and the territories because of the time lag between increases in mainland costs and their reflection in prices in the territories. ${ }^{27}$

But even before the GCPR was replaced in the territories generally, special action was taken to exempt the Panama Canal Zone from price regulation. ${ }^{28}$ The United States Government in effect had a monopoly on the supply of goods to the armed forces and other residents there, and prices were kept purposely low. Under these circumstances the indirect control established by ceilings on supplies in the United States was considered sufficient.

Exporters and importers also were initially covered by the GCPR. Especially in the case of importers, however, it was clear that the general freeze would soon be replaced by a specific regulation. Obviously, long-term price policies for imported commodities would have to be based on different considerations than those applicable to domestic goods. The freeze itself applied only to prices charged in this country. The United States, of course, had no direct control over prices charged by foreign sellers outside this country, ${ }^{29}$ so that the GCPR in effect froze importers' prices without freezing their costs.

A special regulation for importers and imported commodities was issued in May I95I. ${ }^{30}$ Later, a specific regulation for exporters was also issued. ${ }^{31}$ The export problems were not so urgent because exporters' costs were more subject to control and because Section Io(a) of the GCPR in effect permitted exporters to maintain their customary differentials between prices on domestic sales and prices on export sales.

Although special factors involving foreign trade and foreign relations existed in connection with both exporters and importers, it was found necessary to have price controls on both kinds of sellers if the effectiveness of a general freeze was

${ }^{26}$ GOR 27, I7 FED. REG. 2923 (I952); Amendments 2 and 3, 17 FED. REG. 8628, I1646 (1952).

${ }^{27}$ CPR 9, I6 FED. REG. 2183 (195I), replaced the GCPR for all commodities sold in the territorics and possessions but not manufactured there.

${ }^{28}$ SR 6 to the GCPR, I6 FED. RiEg. I79I (I95I).

29 The United States could not impose legal ceilings on the prices foreign sellers charged on sales consummated abroad, although this country could prohibit importers from paying foreign sellers prices higher than those consistent with domestic ceilings. Great Atlantic and Pacific Tea Co. v. Porter, 156 F. 2 d 812 (E. C. A. 1946). But while the United States could have set buying ceilings on importers, this was not practicable as part of a general freeze.

${ }^{30} \mathrm{CPR}$ 3I, I6 FED. REg. 4184 (I95I).

${ }^{31}$ CPR 6I, I6 FED. REC. 7597 (1951). 
not to be seriously impaired. Uncontrolled prices on imported items could well have disrupted efforts to freeze prices on similar domestic goods, especially consumer items. Controls on export prices were necessary to prevent serious diversions which could aggravate the inflationary pressures in the domestic markets and so impair the effectiveness of a general freeze.

\section{Record Keeping Requirements}

Section 705(a) of the Defense Production Act of r950 (50 U. S. C. App. \$2155(a) (Supp. 1952)) authorized the President, while the Act was in effect and for a period of two years thereafter, to require, among other things, the keeping of such records as was necessary or appropriate, in his discretion, to the enforcement or the administration of the Act and the regulations issued thereunder.

Since the central feature of a freeze is that it fixes ceiling prices on the basis of the events during a base period, it is essential to both administration and enforcement of a freeze that base period records be available. ${ }^{32}$ Accordingly, Section $\mathrm{r} 6$ of the GCPR required each seller to preserve those records in his possession showing the prices charged by him during the base period. In addition, each seller was required to prepare (I) a statement of the categories of commodities or services delivered or offered for delivery by him in the base period; (2) a ceiling price list for the commodities and services delivered or offered for delivery by him during the base period; and (3) a statement of his customary price differentials for terms and conditions of sale and classes of purchases, which he had in effect during the base period.

Wholesalers and retailers were also required to preserve sufficient records to establish the latest net cost incurred by them prior to the end of the base period in purchasing commodities delivered or offered for delivery during the base period. This information was necessary as a basis for fixing ceilings on other commodities in the same categories.

Operators of restaurants were required to preserve all menus used by them in the last ten days of the base period. Retailers were allowed to prepare their base period ceiling price list by recording on their purchase invoices the prices at which the commodities were delivered or offered for delivery in the base period.

Section 16 specified not only that these records be prepared and preserved, but also that they be available for examination by OPS. This was necessary if the records were to serve fully their purpose of assisting in securing compliance with and enforcement of ceiling prices. The section did not, however, specify how long the records had to be kept. Later regulations followed the language of Section 705(a) of the Act and required that base period records be kept for the life of the Act and two years thereafter. Although Section 16 read literally seemed to require that base period records be kept indefinitely, by interpretation the requirement was held to be limited by the statutory authorization. ${ }^{33}$

${ }^{32}$ The general availability of base period records is a factor to be considered in selecting a base period; generally the more recent the base period, the more likely it is that adequate base period records can be found or prepared.

${ }^{33}$ This was confirmed when price controls were terminated in 1953, by GOR 44, I8 FED. REG. 
The statement of categories and the ceiling price list for all commodities or services delivered or offered for delivery during the base period, were required to be prepared on or before March $\mathrm{x}$, I95r. This deadline was postponed, for retailers, to March 22, $195 \mathrm{I}^{34}{ }^{34}$ because a retailers' regulation was in preparation which made unnecessary for some retailers the preparation of these statements. ${ }^{35}$

Closely akin to the base period record requirement, in the sense that it also related to the establishment of ceiling prices, was a provision that records showing how a seller determined ceiling prices for commodities and services not sold by him during the base period be kept for two years. The GCPR also required each seller to keep for two years records of the kind which he customarily kept with respect to current sales showing the prices he charged.

In later regulations, a more consistent practice was developed of requiring base period and other records relating to the establishment of ceiling prices to be preserved for the life of the Act and two years thereafter, whereas records relating to current sales were generally required to be kept for two years from the date of the transaction. This was believed to give OPS a reasonable time in which to complete investigations and not to impose unreasonable burdens on business concerns. Also, the requirements regarding records of current sales were spelled out in greater detail in later regulations, which usually required as a minimum record the date, the seller's name and address, the buyer's name and address, a detailed description of the kind and quantity of items sold, the prices charged, and the terms and conditions of sale. Frequently, commercial or industrial buyers were also required to keep similar records regarding their purchases.

These more detailed record keeping provisions would not have been appropriate in a general freeze covering a great range and variety of commodities, services, sellers, and buyers. Detailed records of each sale obviously would have been inappropriate for retailers, for example.

The GCPR also required any seller who had customarily given a purchaser a sales slip or receipt, to continue to do so. Furthermore, upon request by a buyer, any seller, regardless of previous custom, was required to give the purchaser a receipt showing the date, the name and address of the seller, the name of each commodity or service sold, and the price received for it.

II

\section{EXEMPTIONS}

A basic decision inherent in the concept of a "general" freeze is that practically all items subject to control shall be covered. It was therefore decided to list those things to be excluded, rather than those to be included, since the exclusions would comprise a much shorter list. This decision imposed the administrative burden

1477 (1953), which provided that in no event were records required to be kept after April 30, 1955, or two years after the termination on April 30, 1953, of Title IV of the Defense Production Act of 1950 dealing with price controls.

34 Amendment 3 to GCPR, I6 FED. REG. I79r (I95I).

${ }^{35}$ CPR 7, Retail Ceiling Prices for Certain Consumer Goods, I6 FED. REG. I872 (1951). 
of identifying and listing those specific areas where controls could not or should not be imposed because of legal prohibitions or limitations, administrative difficulties, or the necessities of the defense program.

In recognition of its interim character, and in contemplation of the issuance of other regulations to replace it, the GCPR provided that it did not apply to commodities or services for which ceiling prices were then or later fixed by other OPS price regulations. This provided an automatic and continuing mechanism whereby items were excluded from the GCPR when and as they became subject to other regulations.

In a few instances, items intended to be brought under specific regulations were exempted from the general freeze in anticipation of specific regulatory action. These cases were the exception; the general rule was that commodities, services, and transactions intended to be covered by specific tailored regulations were to be subject to the general freeze until specific tailored regulations could be prepared and issued.

Nevertheless, the few exceptions do illustrate the two functions of exclusions from the general freeze: one-to exclude times which must or should be exempt from all price controls; and two-to exclude items which should be exempt from a general freeze but not from control under specific tailored regulations. ${ }^{38}$

\section{A. Statutory Exemptions}

When the GCPR was issued Section 402(e) of the Defense Production Act (50 U. S. C. App. \$2102(e) (Supp. 1952)) exempted the following from price control:

I. Prices or rentals for real property.

2. Fees for professional services.

3. Prices or rentals for materials for publication by any press association or feature service, or for books, magazines, motion pictures, periodicals, or newspapers, other than as waste or scrap; and rates charged by a newspaper, periodical, magazine, radio broadcasting or television station, motion picture or other theater enterprise, or outdoor advertising facilities.

4. Rates charged in the insurance business.

5. Rates charged by any common carrier or other public utility.

6. Margin requirements on any commodity exchange. ${ }^{37}$

These exemptions were listed in Section I4 of the GCPR. In the main, they covered areas not controlled during World War II and for which it was thought not desirable to permit controls. ${ }^{38}$

${ }^{30}$ OPS adopted specific techniques for dealing with these different kinds of exemptions. Exemptions from the GCPR only were listed in the GCPR itself or in a supplementary regulation to the GCPR. Exemptions from all price controls were listed in general overriding regulations which made the exemptions effective not only as against the GCPR but also any other regulations issued by OPS.

${ }^{37}$ Exemptions identical to numbers $2,3,4$, and 5 above were included in Sec. $302(c)$ of the Emergency Price Control Act of $\mathrm{r} 942$, except that the 1942 Act for obvious reasons contained no specific reference to television stations.

${ }^{38}$ Rent controls for housing accommodations had been authorized under the Emergency Price Control Act of 1942, as amended, and continued under the Housing and Rent Act of 1947. 6I STAT. 193 (1947), as amended, 50 U. S. C. App. \$1881 (Supp. 1952). Thus authority to maintain rent controls under certain circumstances was still in effect under a separate statute when the Defense Production Act of 1950 was enacted, and rent controls were being administered by the Office of Rent Stabilization. 
A number of interpretative problems centered around the general question whether royalties or payments for the right to enter on property represented a sale or rental of real property or of a commodity or service. Thus, OPS took the position that the furnishing of the usual parking facilities constituted storage services. Most parking lot fees and charges were held to be subject to the GCPR, and later to the services regulation, CPR 34, and remained generally under price control until the termination of the program in $1953^{39}$ Similarly storage of boats by a shipyard was held to be a storage service rather than rental of real property. ${ }^{40}$ An exclusive license to take coal or other natural resources from land upon payment of royalties was not a sale or rental of real property but the sale of a commodity. ${ }^{41}$ Also held subject to the general freeze were fees for licenses to enter upon land and leave things there. ${ }^{42}$

In general, the exemption for sales or rentals of real property did not cover charges for privileges or services connected with real estate, such as storage services, maintenance and janitorial services, and others of like character.

Neither the Act nor the GCPR originally specified the services included in the exemption of professional services. Services performed by beauty shops and barber shops were not considered professional services, ${ }^{43}$ although in 195 I Section 402 (e) was amended ${ }^{43^{a}}$ to exempt these services.

In general, the statutory exemption applied to those services where the work performed was based on knowledge of an advanced type as contrasted with the application of skill. Generally, also, professional services consistently required the exercise of discretion and judgment, and could not be standardized, so that administratively it would be most difficult to control fees for such services. In addition to doctors and lawyers, professional engineers, architects, and certified public accountants seemed clearly within the statutory exemption.

In July 195r, OPS exempted a long list of services, such as those of accountants, dentists, engineers, lawyers, musicians, optometrists, physicians, statisticians, and teachers. ${ }^{44}$ The Statement of Considerations did not identify which were statutory exemptions and which were exempt for administrative reasons, but stated that one of the purposes of the action was to set forth the professional services exempt by the Act.

Included was an exemption for prescriptions. OPA had ruled that the identical professional service exemption in Section 302(c) of the Emergency Price Control

${ }^{30}$ See Interpretations, OPS Loose Leaf Service, 85 Serv 32:218.3. Also Report and Recommendation of the Board of Review, In the Matter of the Avenue Company, Protestant, OPS Loose Leaf Service, 20I OP I3I. The Board's report was adopted as the opinion of the Director in the order dated March 26, 1952, denying the protest. OPA had taken the same position and was upheld in the courts. Sce Carothers v. Bowles, r48 F. 2d 554 (E.C.A. 1945), cert. denied, 325 U. S. 875 (1945).

${ }^{40}$ Interpretations, OPS Loose Leaf Service, 85 Serv. 32:202.55.

${ }^{41}$ GCPR Interpretation 36, x6 FED. REG. 4192 (1951). In $x 952$, for administrative reasons, royaltics paid to a landowner in connection with the mining of iron ore were exempted from price control. Amendment 32 to GOR I4, I7 FED. REG. II646 (r952).

12 Interpretations, OPS Loose Leaf Service, 85 Serv $32: 202.33$.

${ }^{43}$ GCPR Interpretation 37, I6 FED. REG. 4192 (I95I).

13a 65 STAT. I3I, I35 (195I), 50 U. S. C. App. \$2102(e)(vii) (Supp. 1952).

"4 GOR I4, I6 FED. REG. 6664 (I95I). 
Act of 1942 did not apply to the filling of a prescription by a pharmacist, on the ground that such a transaction involved the sale of a commodity. ${ }^{45}$ Accordingly, OPS could have adopted the same construction, on the theory that the re-enactment of the language of the Price Control Act constitued a ratification of the OPA ruling. However, in the discussion on the Senate floor on the conference bill which became the Defense Production Act, it was stated that the conferees had agreed that the professional services exemption applied to fees charged by a pharmacist in filling a prescription. ${ }^{46}$

OPS sought to escape the dilemma by exempting the fees of pharmacists for filling prescriptions only (I) if the prescription contained written directions for use signed by a physician, ${ }^{47}$ (2) if it required the services of a registered pharmacist, and (3) if the pharmacist transposed the written directions from the prescription to the label on the package. A sale of a product by a registered pharmacist which did not meet these three conditions was treated as a sale of a commodity and not exempt. ${ }^{48}$

The reluctance to exempt all sales by registered pharmacists was because in many cases the "professional service" aspect of the transaction was completely subordinate and incidental to the sale of a commodity. Medicine, drugs, and medical supplies purchased from drug stores employing registered pharmacists represented a substantial volume of dollar sales, and OPS was reluctant to remove all controls from what could be an important element of cost for many consumers.

Physicians also occasionally supply their patients with drugs or medical supplies. This activity on the part of a doctor, however, is clearly only incidental to his principal function, which is the furnishing of professional services. Because of the practical difficulties of separating the purely professional services of a doctor from his incidental sale of medicines, the entire transaction was considered exempt as a professional service. This approach was more justified, of course, where the furnishing of the commodity was an exceptional and incidental part of the transaction, as in the case of doctors, than where the supply of the commodity was the primary and usual feature of the transaction, as in many cases of filling prescriptions.

OPS also took the position that the sale of frames, lenses, and other opthalmic supplies by optometrists constituted sales of commodities. A year after the issuance of the GCPR, however, OPS acquiesced in the requests of optometrists that both the services they rendered and the furnishing of opthalmic supplies be exempt. ${ }^{49}$ The action was limited to services and supplies furnished by an optometrist in making and filling his own prescription, however, so that the sale of supplies pre-

\footnotetext{
${ }^{45}$ Letter of July 21, 1942, from Price Administrator Henderson to the National Association of Retail Druggists.

${ }^{60} 97$ CONG. REC. I4060, 14074 (1950).

${ }_{47}$ A subsequent amendment extended the scope of the exemption to cover the case where a practitioner furnished an oral prescription and promptly thereafter reduced it to writing. Amendment 3I, GOR I4, I7 FED. REG. II443 (I952).

${ }^{48}$ See memorandum of April 2I, 195r, from Harold Levanthal to Alfred Letzler.

"A Amendment 6 to GOR I4, I7 FED. REG. 545 (I952).
} 
pared in accordance with someone else's prescriptions or not based on a prescription continued to be subject to ceilings as a sale of commodities. ${ }^{50}$

The exemption for the press, publications, and broadcasting and theater enterprises, like the similar exemption in the Emergency Price Control Act, was intended as a guarantee that price controls would not interfere with the media of public information. 51 The exemption for a "motion picture or other theater enterprise" included symphony orchestras, operas, and ballets. ${ }^{52}$ It did not, however, include such affairs as sports events, or automobile or livestock shows, ${ }^{53}$ in view of the statutory purpose to protect freedom of expression. ${ }^{54}$

The exemption for outdoor advertising facilities apparently was an attempt to put these enterprises in a comparable position to that of newspapers and other periodicals, whose advertising charges were exempt. Rates for advertising which was neither on outdoor facilities nor in newspapers or periodicals, however, were not exempt.

The exemption for insurance rates was apparently based on a belief that these rates were already adequately controlled under state law. A seller of commodities who made a charge for a warranty of serviceability was not in the insurance business within the meaning of the statutory exemption, however, and the warranty was considered to be a service for purposes of price control. ${ }^{\mathbf{5 5}}$

The exemption for margin requirements on commodity exchanges was not included in the Emergency Price Control Act of r942. Apparently it was felt that such controls were not needed because of the belief that voluntary action by the exchanges themselves was adequate.

I. Exemptions for Common Carriers and Other Public Utilities. Rates charged by common carriers or other public utilities were exempt because of the belief that their charges were generally regulated by other public regulatory bodies. The Act, itself, however, exempted all public utilities whether their rates were regulated by a governmental agency or not. Since the rates of many common carriers and other public utilities in fact were not subject to regulation by any public body, the statutory exemption left a substantial area subject to no controls at all. ${ }^{50}$ This created administrative difficulties for OPS with regard to related controlled areas. For ex-

\footnotetext{
${ }^{50}$ Amendment $I_{4}$ to GOR I4, I7 FED. REg. 4292 (1952), stated that the exemption applied to the filling or refilling of his own prescription by an optometrist.

${ }^{51}$ Consistent with this legislative policy, OPS later exempted printed commodities whosc primary value depended on editorial comment, expression of ideas, or dissemination of information, as well as the printing and allied services in connection therewith, Amendment I to GOR 8, I6 Fed. Reo. 4493 (I95I).

${ }_{62}$ OPS General Interpretatons 5, I6 FED. REG. 11686 (195I); OPS Loose Leaf Scrvice, 42 Reg 95:1.

${ }^{63}$ Interpretations, OPS Loose Leaf Service, 85 Serv 32:202.16; 85 Serv 61:203a.23. Also sce SR II to CPR 34, I7 FED. REG. 820 (r952) (specifying dollars-and-cents ceilings on admission charges to major league professional baseball games).

it In the Defense Production Act Amendments of 1952, Congress included a special provision cxempting prices charged by bowling alleys. Sec. 109(c), 1952 Amendments. 66 STst. 296, 299 (1952).

${ }^{50}$ Interpretations, OPS Loose Ieaf Service, 85 Serv $32: 202.43$.

${ }^{50}$ In construing a similar exemption under the Emergency Price Control Act of 1942, the Emergency Court of Appeals held that the exempting clause applied to all common carriers without exception, and was not limited to those whose rates are regulated by other federal or state authorities. Dunham and Reid v. Porter, I57 F. 2d 1022 (E.C.A. 1946).
} 
ample, contract carriers who were subject to control could see no justification for the statutory exemption of those common carriers who were not subject to rate regulation by any other public agency and so were left free of any controls.

The Defense Production Act contained no definition of a public utility. A decision of the United States Supreme Court, however, construing a similar exemption in the Emergency Price Control Act of $1942,{ }^{57}$ contained an analysis of the problem which OPS used as a guidepost in the administration of the Defense Production Act.

The Supreme Court held that even a business not usually identified as a public utility would still be included in the statutory exemption if it had been appropriately classified as a public utility by a federal, state or local law, and if its rates were actually regulated by a federal, state or local regulatory body exercising rate regulatory jurisdiction. In holding a warehouse in that case to be a public utility, the Supreme Court said that Congress had not intended to supersede the power of a state regulatory commission exercising comprehensive control over the prices of a business appropriately classified as a public utility by the state constitution and by state statute.

The identification of a public utility entitled to the statutory exemption presented the least problems, of course, in those cases involving a "conventional" utility such as a gas or electric light and power company. Where one of these held itself out to serve the general public upon reasonable demand, at fixed uniform rates, it was exempt even if its rates were not subject to regulation by some public body.

On the other hand, a business was not a public utility if it did not hold itself out to serve the public at fixed nondiscriminatory rates. Thus, a motor carrier of milk, who was free to change his service and route at will, was not a common carrier under the statutory exemption..$^{58}$

Other services or commodities sold by a public utility did not come within the statutory exemption unless they were an incidental and inseparable part of the public utility service or unless they were regulated as a public utility service. The sale of equipment was not generally regarded as part of the rate charged by a public utility and so was not exempt. ${ }^{59}$

The extension of the public utility exemption to businesses not in the conventional public utility category, though required by the Supreme Court's decision, made it look as though OPS were exempting some public utilities-those whose rates were subject to public regulation-and refusing to exempt others-whose rates were not so regulated. Yet, as the Supreme Court concluded, it was only logical that in a borderline case the question whether a particular service was a public utility should be made to turn on whether it was classified and regulated as a public utility under federal, state or local law.

One difficulty the layman had with this approach, of course, was that the same kind of service was subject to price control in one state or community and exempt in another. As an example, some terminal facilities, classified as public utilities by

\footnotetext{
${ }^{57}$ Davies Warchouse Co. v. Bowles, 32r U. S. I44 (1944).

${ }^{58}$ Interpretations, OPS Loose Leaf Service, 42 Reg I I :2I4f.3.

${ }^{50}$ Interpretations, OPS Loose Leaf Service, 42 Reg Ir:2I4f.Ir.
} 
the applicable state laws and under effective regulatory jurisdiction of local governmental units, were exempt from price control. Others, including some municipal facilities, performing the same functions but not classified and regulated under state law as public utilities, were not exempt.

OPS, for administrative reasons, had exempted services furnished directly by a federal, state or local government unit but had excluded from the exemption terminal, dock and warehouse services. ${ }^{60}$ During the pendency in the Court of Appeals of appeals from the denial by OPS of protests filed by certain West Coast municipally owned port facilities operating cold storage warehouses, further administrative action was taken to delete this exception, so that terminal, dock and warehouse services furnished by governmental units were included in the general exemption of governmental services. ${ }^{61}$ The complaint in the Emergency Court of Appeals was thereupon dismissed as moot. ${ }^{62}$

The controversy over the regulation of marine terminal services, however, was directly or indirectly related to two further statutory exemptions added to the Defense Production Act in 1952. The first of these extended the public utility exemption already in the Act to include rates charged by any person subject to the Shipping Act of $19166^{63}$ Common carriers by water, who were subject to the Shipping Act of I9I6 and whose rates were subject to regulation by the Federal Maritime Board, were already exempt from the Defense Production Act as common carriers. The only effect of the 1952 amendment thus was to bring within the exemption marine terminals, which were subject to the Shipping Act and to the jurisdiction of the Federal Maritime Board but only for the purpose of preventing discriminatory rates and practices.

The other 1952 amendment provided an exemption for materials or services supplied by the states, territories, and possessions of the United States, their political subdivisions and municipalities, the District of Columbia, and any agency of any of these. ${ }^{64}$

Oddly enough, this general exemption did not include materials and services supplied by agencies of the Federal Government. Apparently this decision was influenced by the fact that the Federal Government was a seller of metal scrap, and the belief that a blanket exemption would have serious effects on scrap prices. OPS, however, by various administrative actions, issued miscellaneous exemptions for sales of commodities by different agencies of the Federal Government and as indicated above had issued a general exemption for sales of services by the Federal Government as well as state and local governments.

The West Coast municipal corporations operating cold storage warehouses had contended, among other things, that the rates for those facilities were regulated by

${ }^{\circ 0}$ Amendment 2 to GOR I4, I6 FED. REg. 9563 (r95I).

4 Amendment 9 to GOR 14 , I7 FED. REg. 2657 (1952).

o2 Judgment dismissing complaint dated June 17, I952, Port of Seattle and Port of Tacoma v. Arnall, No. 594, Emergency Court of Appeals.

${ }^{3}$ Sec. Iog(b), Defense Production Act Amendments of 1952, supra note 54 .

. 4 Sec. yog(c), Defense Production Act Amendments of 1952, stipra note $54^{\circ}$ 
a governmental regulatory body because each municipal corporation fixed its own prices under statutory authority. This argument, which was rejected by OPS, could have been made, of course, by any governmental unit selling a commodity or service. The argument furthermore would have in effect read government agencies out of the definition of "person" in the Defense Production Act, which specifically included the United States or any other government.

It was clear under the Emergency Price Control Act of 1942 and originally under the Defense Production Act of $195^{\circ}$ that Congress meant to include federal, state and local government agencies as persons subject to price control. ${ }^{65}$ The 1952 amendment indicated a shift in congressional intent in so far as state and local governments were concerned.

Congress in I952 also exempted a number of miscellaneous services performed by or for common carriers. ${ }^{66}$.

\section{B. Statutory Limitations-Agricultural Commodities}

The first sentence of Section 402(d) (3) of the Defense Production Act (50 U. S. C. App. \$2102(d) (3) (Supp. I952)) prohibited ceilings on any agricultural commodity below the parity price for the commodity as determined by the Secretary of Agriculture. A general freeze, therefore, could not legally fix ceilings on agricultural commodities based on selling prices in the base period if those selling prices were below the parity prices. ${ }^{67}$

Section I4 of the GCPR exempted raw and and unprocessed agricultural commodities sold by a producer, even where an agricultural commodity was at or above the statutory minimum price. On the other hand, the regulation fixed ceilings on distributors' prices even for agricultural commodities selling below the statutory minimum. However, distributors' ceilings were subject to the parity adjustment provision in Section II, under which the exact amount of increases in prices paid producers could be passed on through all subsequent stages of distribution.

The Statement of Considerations explained the exemption as follows:

Raw and unprocessed agricultural commodities when sold by the producer have been exempted, first, because the freeze technique is at present administratively impracticable when applied to sales by individual farmers, and, second, because the current prices of most such commodities are below the minimum price levels at which ceilings may be established under the Act.

${ }^{\circ 5}$ See, with respect to the identical definition in the Emergency Price Control Act of I942, Case v. Bowles, 327 U. S. 92 (I946); Hulbert v. Twin Falls County, 327 U. S. 105 (1946).

${ }^{\circ 0} \mathrm{Sec}$. rog(b), Defense Production Act Amendments of 1952, supra note 54. These additional statutory exemptions were specifically set forth in Amendment I8 to GOR I4, 17 FED. REG. 6703 (I952). Some of these had been previously exempted by OPS on administrative grounds by Amendment 11 to GOR I4, I7 FED. REG. 3234 (1952), but the exemptions for toilet and parking facilities operated by common carriers were new.

${ }^{-7}$ Sec. $\mathrm{ro4}_{4}$ (b) of the Defense Production Act Amendments of 195I, supra note 43a, added an additional limitation, prohibiting a ceiling for any agricultural commodity below 90 per cent of the price received by producers on May 19, 1951, as determined by the Secretary of Agriculture. This was part of the anti-rollback legislation adopted in 195I; it was not, of course, a problem in January, 195I, when the general freeze was-issued. 
Section 402 (d) (3) of the Act also prohibited ceilings on any commodity processed or manufactured in whole or substantial part from any agricultural commodity below a price which would reflect to producers of the agricultural commodity a price equal to the statutory minimum, usually the parity price. To avoid any conflict with this provision, Section Ir, the so-called parity pass-through section, permitted the amount of increases in prices of agricultural commodities to be added to their ceilings by processors and manufacturers. ${ }^{68}$

Neither the Defense Production Act nor the GCPR defined agricultural commodity. For the purposes of the first sentence of Section 402(d) (3), however, only commodities for which the Secretary of Agriculture fixed parity prices were considered agricultural commodities ${ }^{69}$ Since the statutory limitation required a comparison with parity prices, the agricultural commodity provision could be applied only where there was a parity price determination. A broader definition of agricultural commodity might have made it impossible ever to impose ceilings on commodities for which the Secretary of Agriculture did not determine parity prices, a conclusion clearly not intended. The listed agricultural commodities eligible for "parity adjustments" under Section II were those for which the Secretary of Agriculture had in fact determined parity prices.

The first amendment to the GCPR limited the exemption to the specific agricultural commodities which were then selling below parity, but expanded the exemption to include all sales, not only producers' sales, so long as the agricultural commodity was sold in its raw or natural state, or in the first form or state in which it was customarily sold by producers. ${ }^{70}$ One purpose and effect of this was to include in the exemption transactions on the commodity exchanges.

Commodities selling below parity are not likely to be in short supply, and it was believed that competition should be effective in holding distributors' margins in line. In addition, it was stated that ceilings determined by the freeze technique were not suitable for transactions on commodity exchanges. ${ }^{71}$

Since a major reason for the exemption of agricultural commodities selling below parity was the statutory obligation to allow these commodities to reach parity levels, OPS was concerned with the problems of terminating the exemption when the statutory conditions were satisfied. The first step, as indicated, was to limit the exemption to commodities actually below parity levels. Then, as a further step, it was provided that the exemption and the parity adjustment benefits would terminate automatically five days after the date on which the Secretary of Agriculture announced by publication a prevailing price for an agricultural commodity which satisfied the statutory minimum..$^{72}$

\footnotetext{
${ }^{88}$ This parity adjustment provision is discussed in greater detail in another study.

${ }^{6 \theta}$ See, for example, Opinion, Legislation, Research and Opinions Division, Office of Chief Counsel, OPS Manual Pt. 5, c. 3, \$2.55.

${ }^{70}$ Amendment I to GCPR, I6 FED. REG. 1503 (195I). The amendment also made it clear that the exemption of specified agricultural commodities applied to imported as well as domestic commodities.

${ }^{71}$ Earlier, OPS had issued SR 3 to the GCPR, I6 FED. REg. 1503 (I95I), which included a section prescribing special ceilings for certain agricultural commodities selling above parity and sold on commodity exchanges.

${ }^{72}$ Amendment 7 to GCPR, I6 FED. REG. 2546 (195I). The amendment further provided that
} 
Subsequently, OPS reversed itself on both steps. ${ }^{73}$ It found the provision for automatic deletion from the list of agricultural commodities eligible for parity adjustments unnecessary, since the Director of Price Stabilization was able to act promptly by specific amendment when a parity level was reached. This procedure avoided confusion as to which commodities were or were not on the list, and also retained in the Director greater flexibility to make such specific provisions as might be found necessary to maintain a balanced price structure.

At the same time, OPS reverted to the original technique whereby sales of agricultural commodities were exempt, at the producer level, whether they were selling below or above parity. Subsequent sellers were brought back under margin control, even on commodities selling below parity. The Statement of Considerations indicated that the freeze technique was administratively impracticable for fixing ceilings for individual farmers, and that the regulation of distributors' margins would be the most effective method of control in this area.

Almost immediately it was discovered that the exemption of producers' sales only had "inadvertently" brought commodity exchange transactions back under control. The exemption was again revised to include sales on commodity exchanges of raw agricultural commodities selling below parity. This was accomplished by making agricultural commodities in their raw or natural state exempt generally, but limiting the exemption for a seller other than a producer to those commodities listed as being below parity levels. ${ }^{74}$

An agricultural commodity in its raw or natural state generally meant only the raw materials produced on the farm, before they were refined, manufactured or processed. Products derived from agricultural commodities, even though considered raw materials for manufacturing or processing purposes, were not entitled to the exemption.

\section{Administrative Exemptions}

Section 402(f) of the Defense Production Act (50 U. S. C. App. \$2ro2(f) (Supp. I952)) authorized exemptions where necessary to promote the national defense, or where ceilings were not necessary to effectuate the purposes of the stabilization program. Under this statutory authority OPS embarked on a program of administrative exemptions which began with the issuance of the GCPR and continued up to the termination of price controls in 1953 . The policies and standards evolved under this continuing program, although they had their beginnings in the GCPR, are not within the scope of this study. Even so, any study of a general freeze would be incomplete without at least a description and a brief analysis of discretionary exemptions.

The early exemption policy was based on a desire to avoid interference with essential supply of military materials or services, and also on the feeling that a better

upon termination of an exemption, ceilings were to be determined under the GCPR, but using the most recent five week period preceding the date the exemption was removed, as a base period.

${ }^{73}$ Amendment 13 to GCPR, I6 FED. REG. 505I (r95I).

it Amendment 14 to GCPR, I6 Fed. REg. 5II9 (I95I). 
over-all job of stabilizing the economy could be done if the time and energies of the agency were not dissipated on matters of no real importance. Yet, it was recognized that a balance had to be struck between these considerations and the fundamental objective of stabilizing prices across-the-board. Too free a hand with exemptions of "essential" materials and services could have carved such a large slice out of the GCPR that the regulation would have become a hollow shell of a "general freeze." Substantial areas were already beyond the control of the agency because of the statutory exemptions and the statutory limitations with respect to agricultural commodities.

Even a program of exemptions of items apparently of little significance had to be administered with care. Most any industry could be fragmentized to such a degree that each separate little part, treated by itself, would appear to be so insignificant as not to make ceilings necessary. Yet, if carried far enough, this process could include in the aggregate such a substantial part of the nation's economy as to make serious inroads in the coverage of the general freeze, and its value as a general lid on prices. In addition, exemption of items having little direct stabilization impact might result in the diversion of necessary manpower and materials from more important activities. Notwithstanding these obvious dangers of any exemption program under a "general" freeze, OPS, as OPA had, did exclude a number of materials and services from the general freeze. In the main, these exemptions served to give the agency more time to deal with the more important problems arising under the GCPR. ${ }^{75}$

Underlying most of the exemptions was the administrative difficulty of imposing controls on a particular commodity, service, or seller. In some cases, the administrative difficulty, while not insurmountable, led to exemption because of the insignificant nature of the item and the consequent belief that the benefits to the stabilization program of controls were not worth the trouble. In other cases, the administrative difficulties were so serious, on an absolute basis, that controls were considered impractical even though an important item was involved. In still other cases, the administrative difficulties were weighed against the possible repercussions on the defense effort in deciding in favor of an exemption.

I. Administrative Exemptions for Unimportant Items. Among the things exempt for reasons of administrative impracticability and relative insignificance in the stabilization program when the GPR was issued were:

Stamps, coins, precious stones, and paintings and other objects of art.

Antiques (commodities made prior to 1850 ).

Used personal or household effects sold by a private owner.

Used household or personal effects sold at a bona fide auction.

Damaged commodities sold by insurance companies, transportation companies, the

United States Government, or by persons engaged primarily in the business of selling

${ }^{75}$ One of the early exemptions after the issuance of the GCPR was for sphygmo-oscillometers. GOR, 5, I6 FED. REG. 3408 (195I). Mr. DiSalle was reported to have stated that this item was exempted so that he would not have to learn how to spell it. 
damaged commodities received from insurance companies, transportation companies or the United States in direct connection with the adjustment of losses.

Abandoned or confiscated property sold by Government agencies or pursuant to a court decree.

American Indian and Eskimo handicraft objects.

Commodities produced by a seller in his own home without assistance of hired employees, not exceeding \$200 per month.

Commodities grown and processed on his own farm by a farmer, not exceeding $\$ 200$ per month.

Many of these exemptions had been included in the GMPR by OPA. Objects of art included paintings, sculptures, and similar unique art products of individual skill. Later OPS also exempted imported oriental rugs, stating they, like paintings and antiques, depended for their value on intangible subjective considerations which made the fixing of price ceilings extremely difficult. ${ }^{76}$ Oriental rugs were also among the nonstandardized luxury items exempted from the GMPR by OPA during World War II.

The exemption for used household or personal effects did not apply to sales by an establishment regularly engaged in selling such commodities other than by auction. This exemption was eventually extended to cover all used supplies or equipment sold by a person who had not acquired or produced them for the purpose of sale. ${ }^{77}$ Most such sales of used supplies or equipment were occasional in nature, had little effect on the general price structure, and were administratively difficult to price under a base period freeze technique. ${ }^{78}$ Scrap and waste materials were not used supplies or equipment under the exemption. Sales of scrap and waste materials, especially by industrial or commercial concerns, in many instances were not occasional in nature but a regular part of a continuing business operation.

The exemption not only was limited to commodities which would otherwise have been subject to the GCPR, but in addition did not apply to commodities for which a specific supplementary regulation to the GCPR had been issued. Thus, used commodities which were important enough to be the subject of a specific ceiling price regulation or a specific supplementary regulation were not exempt. Used passenger automobiles and used machine tools, for example, which were covered by specific regulations, were not exempt. ${ }^{79}$

The exemption of used items relieved the agency as well as sellers of difficult administrative problems. The limitation of the exemption to sales by a person who had acquired the commodity for use, leaving controls in effect on sales by dealers,

${ }^{76}$ Amendment I, GOR 5, I6 FED. REg. 5622 (I95I).

${ }^{77}$ Amendment 26 to GCPR; I6 FED. REG. 12819 (I95I). The exemption did not apply to sales of used commodities by the United States Government, but these were already generally exempted by SR I to GCPR, I6 FED. REG. I006 (I95I), and SR 72 to GCPR, I6 FED. REg. ror59 (195I).

${ }^{78}$ Amendment 29 to GCPR, 17 FED. REG. 1936 (1952), made it clear that the excmption did not apply to used rails or trackwork, sold by railroads not on an occasional basis but regularly at standardized prices.

${ }^{70}$ SR 5 to GCPR, I6 FED. REg. I769 (I95I) (used automobiles); CPR 80, I6 FED. REg. I0254 (I95I) (used machine tools). 
was a safeguard against price excesses on used goods. In times of extreme inflationary pressures, where there are real or speculative shortages, prices for used commodities may well exceed those for new ones. Of course, if shortages were serious enough, exemptions for sales by users might lead to dealers generally being bypassed and all sales being made between the original users and new users. Notwithstanding the possibility of some abuses, the exemption appeared to have been a desirable one, certainly as originally limited to used personal or household effects. While more doubt exists as to the wisdom of the broader exemption of used commodities as part of the original issuance of a general freeze, even this broader action seems desirable to relieve administrative problems in what are largely unimportant areas.

The exemptions for abandoned or confiscated property sold by government agencies or pursuant to a court decree, for damaged commodities sold in connection with adjustment of losses, as well as a subsequent exemption of judicial sales, ${ }^{80}$ were also based on the considerations that the sales involved were of a nonrecurring nature, and so did not usually constitute a continuing factor in business or living costs; such sales constituted an insignificant fraction of total sales, not only in the economy as a whole, but with respect to any particular commodity; and failure to control prices on such sales would not result in substantial pressure on other prices.

These exemptions did not free the commodities absolutely from price control. In the majority of cases covered by the exemptions, the commodities were purchased for resale, and on such resales ceiling price restrictions applied. Thus, in each case, control on resale prices constituted an indirect check on the exempt sales. Furthermore, the exemption for judicial sales specifically did not extend to sales by a trustee or other person engaged in continuing a business under court order.

Commodities made by a seller in his own home for his own account, and commodities grown and processed on his own farm by a farmer, were exempt up to $\$ 200$ a month. The extent of inflation since pre-World-War II days might be measured by the fact that similar exemptions by OPA were limited to sales of $\$ 75$ per month. Under OPS the more liberal figure of $\$ 200$ was soon increased to $\$ 1000$ per month. ${ }^{81}$

Eventually, further to carry out the original intent to exempt commodities sold by very small producers, the exemption was broadened to include any producer whose gross sales were not more than $\$ 25,000$ per year for all units under his ownership and control. ${ }^{82}$ The justification was that retention of controls on these small producers served no worth-while purpose, while exemption would have no appreciable effect on the cost of living, the defense effort, or the level of industrial and commercial costs. Producers of logs, pulpwood, and related forest products, however, were not included in the exemption. It was believed that such a large percentage of these commodities were supplied by small producers that this kind of exemption would have seriously impaired price control for those commodities.

${ }^{80}$ GOR 28 , 17 FED. REg. 3677 (1952).

81 Amendment 19 to GCPR, 16 Fed. Reg. 10310 (1951).

${ }^{82}$ Amendment 33 to GCPR, I7 FED. Reg. 7487 (1952). 
A small business exemption for services, included in the general overriding regulation covering services exemptions, exempted services supplied by any individual in his own home if the total amount sold in the preceding year did not exceed $\$ 5000 .^{83}$ A regulation for expanded exemptions of small service establishments, comparable to the small producer exemptions, was well advanced in OPS by late 1952 , but was never issued because of the accelerated program for termination of price controls.

Another small business exemption covered printers whose printing business was not more than $\$ 50,000$ in the preceding year. ${ }^{84}$ OPA had a similar exemption, limited, however, to printers whose annual sales did not exceed $\$ 20,000$.

The pricing of new commodities was one field in which the freeze technique was least effective. In an effort to minimize the administrative problems in this area, OPS early developed procedures for exempting new insignificant or experimental commodities, at least until their sales volume reached a level where controls became practicable and worth while.

The first action in this direction was the exemption of small quantity sales of new and experimental chemicals by producers. ${ }^{85}$ A new chemical was one not sold by the manufacturer during or prior to the base period, and it was exempt until total sales of that item exceeded $\$$ rooo. Experimental chemicals were exempt even after sales reached \$1000, provided OPS did not disapprove the manufacturer's report explaining, among other things, why the chemical was considered to be in the experimental stage and stating the volume of production which would represent commercial production. Experimental products in some other commodity areas were also exempt, such as experimental rubber products, ${ }^{86}$ drugs, ${ }^{87}$ and metals. ${ }^{88}$ Also, in order to reduce reporting requirements and the administrative work load on OPS, the amount of total sales of an experimental item exempt without the necessity of filing a report was raised to $\$ 25,000$.

Exemptions of small quantity sales of new and experimental commodities served a valuable purpose in minimizing the administrative burdens on OPS and manufacturers. Even during a period of full-scale mobilization, there are always numerous new products being introduced, many of which are short-lived and of insignificant importance to the economy so long as sales are in small quantity. This was even more true in a period of partial mobilization such as I950-I953. These new products presented problems which required a disproportionate part of the agency's attention, without making a commensurate contribution to the stabilization program. With proper safeguards, limited exemptions in this area reduced the workload without seriously affecting the effectiveness of controls.

\footnotetext{
${ }^{88}$ GOR I4, 16 FED. REG. 6664 (I95I).

84 Amendment I to GOR 8, I6 Fed.-Reg. 4493 (I95I). Amendment 7 to GOR 8, I7 Fed. Reg. 11816 (I952), made it clear that the exemption covered sales of printed commodities as well as printing services.

${ }^{86}$ GOR 3, I6 FED. REG. 3216 (I95I).

${ }^{80}$ Amendment I to GOR 3, I6 FED. REg. 5056 (195I).

${ }^{87}$ Amendment 5 to GOR 3, I7 FeD. REG. 7275 (I952).

${ }^{88}$ Amendment 25 to GOR 9, I7 FED. REG. 7488 (1952). Originally only experimental ferro-alloys, ferro-metals, and ferro-compounds had been cxcmpted. Amendment i7 to GOR 9, 17 FEd. Reg. 3676 (1952).
} 
Soon after the GCPR was issued, a series of actions authorized exemptions relating to specified nonprofit organizations. These included sales of blind-made products by nonprofit agencies for the blind, ${ }^{89}$ articles bearing official marks of the Girl Scouts and Boy Scouts, sales by the Future Farmers of America, CARE relief packages, official supplies of the $4-\mathrm{H}$ Clubs and the Camp Fire Girls, sales of used and waste supplies by the Salvation Army, Goodwill Industries, Volunteers of America, Society of St. Vincent De Paul, and Junior League, and supplies of the Independent Order of Odd Fellows. ${ }^{90}$ Closely related to these were the early exemptions of charges made by hospitals and educational institutions. ${ }^{01}$

Summer camps not being in operation during the base period of December 20, I950 to January 26 , I951, ceilings would have had to be determined by individual or group applications. The administrative difficulties of setting specific ceilings, coupled with the imminence of the summer camp season, led to a temporary suspension from control of rates for $195 \mathrm{I}^{92}$ The exemption pointed out that camps were quasi-educational, and in many instances were of a nonprofit or charitable nature. When ceiling rates were issued for the 1952 season, the exemption was continued for nonprofit summer camps for children whose charges did not exceed $\$ 30$ per week..$^{03}$ Towards the end of the program, rates of all children's summer camps were exempt. ${ }^{94}$

Charitable, educational and related other nonprofit organizations were the sort of thing that could be exempt from a general freeze, either initially or soon after its issuance, without serious consequences. OPS followed the more cautious policy of exempting certain charitable or nonprofit organizations by name, such as the Salvation Army. It would seem that at least the specific organizations exempted by OPS could be included in the exemptions from a future general freeze without impairing its effectiveness.

The early practice and policy with respect to exemptions of unimportant commodities and services was reflected in an operating instruction issued to the OPS staff in August $195^{1 .} .^{95}$ This instruction, as revised approximately a year later, ${ }^{06}$ stated that exemptions would be approved when the following conditions were satisfied:

I. (a) The material or service does not enter significantly into the cost of living of the average American family or into business costs; or

(b) Control of the material or service involves administrative difficulties for OPS or the sellers of the material or service which are disproportionate in relation to the

${ }^{80}$ GOR I, I6 FED. REG. 2834 (I95).

${ }^{\circ 0}$ GOR 6, 16 FED. REG. 3484 (I95I), and various amendments thereto.

${ }^{02}$ SR 15 to GCPR, 16 FED. REG. 2908 (1951).

${ }^{22}$ Amendment I to SR I5, I6 FED. REG. 3407 (195I). Subsequently, ceiling rates for the 1952 season for summer camps for children were set at either the price charged during the 1950 scason plus 8 per cent, or the price charged during the r95x season, when rates were exempted from control. SR I2 to CPR 34, I7 FED. REg. II84 (I952).

${ }^{03}$ Amendment 8 to GOR, 14, I7 FED. REG. II86 (1952).

Q4 Amendment 3I to GOR' 14, I7 FED. REG. Ir443 (I952).

${ }^{95}$ OPS Price Operations Memorandum No. 5, Exemptions from Price Control, Aug. 5, 195r.

${ }^{0 B}$ OPS MANUAL Pt. 4, c. 1, \$5, Exemption Standards. 
effectiveness of the control or the contribution to the price stabilization program;

2. The material or service is appropriately separable from other materials or services and is not merely a subdivision of a broader area;

3. There is no evidence to show that decontrol of the material or service will have 2 significant adverse effect on the price level when considered in conjunction with previous decontrol of related materials or services;

4. Exemption from control of the material or service presents no substantial threat of diversion of materials and manpower from sellers remaining under control.

2. Exemptions Based Primarily on Administrative Difficulties. While most discretionary exemptions were based in part at least on grounds of administrative difficulties, in most of the cases already discussed the administrative problems justified exemption principally because of the relative insignificance of the commodities, services, or transactions involved.

In the agricultural and food fields, particularly, a number of exemptions based primarily on grounds of administrative difficulty involved relatively important commodities. In many of these cases, the desire to avoid interference with maintenance of supply was also a contributing factor.

The exemption for all raw and unprocessed agricultural commodities sold by producers, which covered a relatively important area, was, as indicated earlier, based upon mixed administrative and statutory considerations. ${ }^{97}$

Fresh fruits, vegetables and tree nuts, ${ }^{98}$ and fresh fish, seafood, and game, were also exempt for administrative reasons. Again, while many fruits and vegetables were selling below parity prices, the exemption was not limited to the below parity items, and unlike the exemption for other agricultural commodities, it was not even limited to producers but applied at all levels of sales. The exemption was justified on the ground that unusual marketing factors and seasonable and perishable characteristics made these commodities subject to sharp and unforeseeable price fluctuations, so that the imposition of a general freeze on these commodities would lead to capricious and inequitable price results. ${ }^{99}$ It was added, however, that as soon as practicable the Director would issue regulations specifically adapted to these unusual factors. ${ }^{100}$

In fact, OPS never attempted to fix ceilings for any fresh fruits or vegetables, except white flesh potatoes, for which a regulation was issued in January I952. ${ }^{101}$

${ }^{97}$ The agricultural commodity exemptions were made applicable to the same commodities produced in the territories and possessions, by Amendment 20 to GCPR, I6 FED. REg. I0384 (I95I).

${ }^{D B}$ This exemption was subsequently expanded specifically to provide that fresh fruits included berries and tree nuts. Amendment 13 to GCPR, I6 FED. REG. 505r (r95I).

${ }^{\circ 0}$ Amendment II to GCPR, I6 FED. REg. 4697 (I95I), added frozen fish and shellfish to the exemption, for the same reasons.

${ }^{100}$ Charges for services in connection with harvesting and marketing of fresh fruits, vegetables, berries, and tree nuts were later exempted by Amendment 2 to SR I5, GCPR, I6 FED. REg. 4 I96 (I95I). This exemption was finally continued indefinitely after the statutory prohibition on ceilings for fruits and vegetables. Amendment 9 to SR x $_{5}$, GCPR, I7 FED. REG. I0543 (1952).

${ }^{101}$ CPR II3, I7 FED. REg. I94 (I952). Potatoes had been exempted previously at all levels of sale because the market prices had been below the level necessary to return the legal minimum to producers. CPR II3 was issued because market prices had advanced up to the legal minimum and threatened to continue advancing. The regulation was revoked on June 24 , 2952, just prior to adoption of a statutory prohibition of ceilings on fruits and vegetables. 
And even this regulation was revoked in anticipation of or in a vain attempt to forestall the 1952 amendment to the Defense Production Act which prohibited the imposition of ceilings on processed as well as fresh fruits and vegetables. ${ }^{102}$

The GCPR also contained an exemption for all live animals, including beef cattle, hogs, and sheep, all important factors in the cost of living. Although the prices of live animals were generally above the minimum standards of the Act, OPS felt that price control could be more adequately effected at that time by freezing prices at the processing and distribution levels only. The Statement of Considerations again prophesied that tailored livestock ceilings would be issued as soon as possible. In taking this approach, OPS recognized the inherent difficulties of setting ceilings on live animals, particularly by a freeze technique. OPS shortly thereafter did issue a regulation which set ceilings on the amounts buyers could pay for live cattle. ${ }^{103}$

Considerations of essential supply loomed large in the exemptions for a list of oil-bearing materials and oils, and for pine gum and American-Egyptian cotton. These items were considered essential to the defense effort, and in the opinion of the Department of Agriculture, ceiling prices at the base period level would have precluded the importation of the oil-bearing materials and oils, ${ }^{104}$ and would have deterred necessary increases in production of pine gum ${ }^{105}$ and American-Egyptian cotton. ${ }^{106}$

Stumpage, the right to sever timber from the stump on the land of another person, had been exempt by OPA, and a supplementary regulation issued soon after the GCPR followed the OPA example. Contributing factors were the administrative difficulties and the fact that a large percentage of timber was owned by federal agencies. ${ }^{107}$ Ceilings continued in effect for lumber and most other wood products.

A combination of seasonal and supply problems led to the exemption of sales of sawmill logs produced and used in Alaska. Because of the seasonal nature of this industry, the base period prices were not appropriate, and OPS administratively was not able to prepare specific ceilings in time for the 1951 season. Rather than disrupt the marketing season, OPS exempted sales for the balance of the $195 \mathrm{I}$ season. ${ }^{108}$

Reagent chemicals for research, hog-cholera virus and anti-hog cholera serum, and crude domestic botanical drugs, exempted by OPS in the early days after the issuance of the GCPR, followed similar actions by OPA. These exemptions were motivated

\footnotetext{
${ }^{102}$ Sec. $106(\mathrm{~b})$, Defense Production Act Amendments of 1952, 66 STAT. 298. This was a part of the general movement toward elimination of all controls.

${ }^{103}$ CPR 23, Live Cattle, I6 FEd. REG. 3696 (I95I).

${ }^{10}$ These included babassu and palm kernels and oils; hemp, kapok, and sunflower seeds and their oils; etc.

${ }^{205}$ The exemption of crude pine gum was limted to producers' sales by Amendment I to GCPR, 16 FED. REG. 1503 (1951).

${ }^{100}$ Amendment 9 to GCPR, 16 FED. REG. 2907 (I95I), extended the exemption of AmcricanEgyptian cotton to include extra long staple cotton grown outside the United States.

${ }^{107}$ SR 17 to GCPR, I6 FED. REg. 3159 (1951). Amendment 1 to SR 17, 17 FED. REg. 1393 (I952), extended the exemption to cover stumps as well as timber.

${ }^{108} \mathrm{SR} 55$ to GCPR, 16 FED. REG. 8893 (195I). The exemption was finally made indefinite by Revised SR 55, 17 FED. REg. 6416 (1952), for fear that an attempt to revert to GCPR base period prices would create a chaotic condition.
} 
by a desire to avoid possible price impediments to the necessary supply of commodities which, while highly important in their uses, were quite unimportant in the cost of living, business costs, or the costs of the defense program. ${ }^{109}$

Several factors led to an exemption for holiday fruit cake made primarily for the Thanksgiving and Christmas holiday seasons. ${ }^{110}$ The purchasing and pricing practices for holiday fruit cake were different from those for other bakery products, and the use of a winter base period freeze was inappropriate because most of the purchasing and pricing took place in the late spring. Because of the imminence of the holiday marketing season, OPS felt that any substantial delay to obtain data necessary for tailored ceilings would be unjustified. On the other hand, OPS's undermanned staff already was fully engaged in many more important projects. Since holiday fruit cake was not important in the cost of living, it was decided to authorize a temporary exemption, which would carry the industry through the holiday season, pending the issuance of a tailored regulation for all bakery products.

Bonds, stocks, and other evidences of indebtedness were exempt from the GCPR, as they had been by OPA under the GMPR. Sales of warehouse receipts, however, were not considered sales of securities but rather sales of the commodities represented by the warehouse receipts. ${ }^{111}$ OPA had adopted a similar position and court decisions had supported its interpretation that sales of warehouse receipts were nothing more than sales of the commodities themselves. ${ }^{112}$ Money order charges were also excluded from the exemption, being regarded as service charges for the transmission and payment of money and the protection of funds rather than as charges for the sale of an evidence of indebtedness. ${ }^{113}$

3. Exemptions -Sales to or by Government Agencies. ${ }^{114}$ The GCPR listed among its exemptions the following (in Section $14(r)$ ):

Sales of military and strategic commodities but only to the extent specified by supplementary regulations or orders which will be issued defining the scope of this exemption.

This provision was given content by Supplementary Regulation I to the GCPR, ${ }^{115}$ containing exemptions from the GCPR which were considered necessary at that time to insure that price controls did not interfere with the defense effort.

SR I, in Section 2, provided a temporary exemption until April I, I95I, for sales of commodities and services normally produced and supplied only for military use, to a defense agency or to any person for use in connection with a defense con-

${ }^{100}$ Reagent chemicals, hog-cholera virus, and anti-hog cholera serum were exempted by GOR 3 , I6 FED. Reg. 3216 (I95I). Crude domestic botanical drugs were exempted by Amendment 3 to GOR 3 , I6 FED. REG. 9478 (I95I).

${ }^{110}$ Amendment 18 to GCPR, I6 FED. REg. 8888 (I95I).

111 Amendment 4 to GCPR, I6 FED. REG. I949 (I95I), clarified the exemption so that it applied to bonds, stocks, and other evidences of indebtedness representing monetary obligations only.

${ }^{112}$ See, for example, Culhane v. Clark, I62 F. $2 d 736$ (E.C.A. 1947).

${ }^{113}$ Sec OPS Manual Pt. 2, c. 3, $\$ 2.35$.

114 A detailed analysis of problems relating to government purchases and sales is set forth in $O P S^{\prime}$ Activities Related to Government Purchases and Sales, by Worsley and Perkins, one of the series of monographs on major problem areas of OPS experience.

${ }^{116}$ I6 FED. REg. I006 (I95I). 
tract or subcontract. "Defense Agency" was defined to mean the Department of Defense, the Maritime Administration, the Coast Guard, and the Atomic Energy Commission. ${ }^{116}$ This exemption was subsequently extended, first to deliveries under a defense contract entered into prior to April $I$, I95I, or pursuant to a subcontract thereunder entered into prior to May $I, I 95{ }^{1},{ }^{117}$ and later to deliveries under defense contracts entered into prior to May I, I95I, or subcontracts thereunder entered into prior to June I, I95I. ${ }^{118}$

Although the exemption under Section 2 was for a temporary period, most items of a strictly military nature were specifically exempt without time limitation under Section 5, on sales to a Defense Agency or to any person for use in connection with a defense contract or subcontract. These exemptions included a list of military weapons and related items such as ammunition. Section 5 also exempted without time limitation a list of specific commodities when especially designed to meet military needs, such as armored vehicles. In addition, a number of other defense items were exempt, including ammunition boxes and aviation gasoline.

The temporary exemption under Section 2 was limited to items "normally produced and supplied only for military use." Thus, if an item was normally supplied by any person for nonmilitary use, the exemption did not apply. ${ }^{119}$ Nor was it enough to show merely that the item was made to military specifications, or that it differed in minor respects from any item made for nonmilitary use. In some cases, military specifications called for products identical with or substantially the same as civilian products. In those cases, the Section 2 exemption did not apply. ${ }^{\mathbf{1 2 0}}$ For example, certain combat boots made to military specifications, which had no civilian counterpart, were exempt. Other types of footwear which were closely akin to civilian items, such as black oxfords, were not exempt, even though made to military specifications. ${ }^{121}$ A similar approach was adopted in administering the indefinite exemption under Section 5 of specified items "especially designed to meet military needs."122

Although the temporary Section 2 exemption applied to an item to be used in a subcontract under a defense contract, the subcontract product itself had to meet the exemption test, "normally produced and supplied only for military use."123

Section 6 of SR I also exempted sales of specified services in connection with a defense-contract or a subcontract. In addition, SR I exempted defense develop-

${ }^{210}$ The Office of Rubber Reserve, Reconstruction Finance Corporation, was included by Amendment 4, SR I, GCPR, I6 FED. REG. 2185 (I95I), to allow applications for adjustments by sellers of soap for use in the manufacture of synthetic rubber.

${ }^{117}$ Amendment 2 to SR I, GCPR, I6 FED. REg. 1707 (195I). By Amendment I, I6 FED. REG. 1234 (1951), sales of certain wool products were included in the temporary exemption for defense contracts.

${ }^{128}$ Amendment 5, SR I, GCPR, I6 FED. REG. 3046 (195I).

${ }^{110}$ Interpretations, OPS Loose Leaf Service, 42 Reg Ir:352a.5.

120 Interpretations, OPS Loose Leaf Service, 42 Reg $I I: 352 a .7$ and 42 Reg $11: 352 a .10$.

${ }^{121}$ GCPR; SR I, Interpretation 2, 16 FED. REG. 3113 (195I); OPS Loose Leaf Service, 42 Reg II:352a.I.

${ }_{122}$ Interpretations, OPS Loose Leaf Service, 42 Reg Ir:355b.r.

${ }^{223}$ Interpretations, OPS Loose Leaf Service, 42 Reg $11: 352 a .6$. 
mental, emergency or secret contracts. The exemption for sales of commodities or services pursuant to a developmental defense contract or subcontract applied only when the appropriate defense agency certified to the Director of Price Stabilization that the particular contract or subcontract was "developmental." A contract was defined to be developmental during the period, not exceeding 6 months, required by the defense contractor for the accumulation of sufficient production experience to permit him to make a reasonably accurate estimate of his manufacturing costs. A defense contract was also deemed developmental during the period, again not exceeding 6 months, required by the purchaser under the defense contract for the selection of a product. The Director of Price Stabilization reserved the right, after consultation with the defense agency, to determine that the period necessary for development had expired and to terminate the exemption.

The exemption for emergency defense contracts applied only when a defense agency set forth the circumstances of emergency which made immediate delivery imperative and which rendered it impossible to secure immediate delivery at the ceiling price which would otherwise be applicable.

For obvious reasons, it was appropriate to exempt sales under a contract which was officially classified as "secret" or above.

SR I also exempted sales of strategic and critical materials to the General Services Administration pursuant to the strategic and critical materials stockpiling program. This exemption was later extended and expanded as an exemption from all price regulations. ${ }^{124}$ In this form, it provided an unqualified exemption of strategic and critical materials mined or produced outside the United States or its territories and possessions, and sold to GSA under the Defense Production Act or the Strategic and Critical Materials Stockpiling Act. ${ }^{124 *}$ As to strategic and critical materials produced in the United States or its territories and possessions and so sold to GSA, the exemption applied if the sale were pursuant to a contract entered into prior to January 25, I95I, or, as to a contract executed after that date, if GSA filed a certification that the marginal or submarginal character of the source or the necessity of additional facilities or equipment made it uneconomic to produce the material at the ceiling price otherwise applicable.

The exemptions in SR I for commodities and services sold to defense agencies or under defense contracts followed in general the similar exemptions authorized by OPA. These exemptions removed from the coverage of the GCPR a very significant portion of expenditures by the military departments for commodities and services, notwithstanding the fact that the cost of military procurement through taxation and the federal budget was an important factor in the cost of living.

It has been noted earlier that both the Defense Production Act and the GCPR defined "person" to include the Federal Government, so that purchases as well as sales by the Federal Government were subject to the price control authority. In fact, Section 401 of the Act (50 U. S. C. App. \$2I0I (Supp. I952)) specifically recited

224 Amendment $\mathrm{I}$ to GOR 2, I6 FED. Reg. 6558 (195I).

124a 60 STst. 596 (1946), as amended, 50 U. S. C. $\$ 98$ (1946). 
that one of its purposes was to assure that defense appropriations were not dissipated by excessive costs and prices.

It was the position of OPS that generally fair and equitable ceiling prices would not impede the production or supply of commodities and services. It is understandable, however, that both the defense agencies and the stabilization agencies would be less likely to remain adamant against allegations that ceilings were impeding production of strictly military and combat items than they would against similar allegations respecting purely civilian items. Recognizing the importance of stabilizing the cost of the defense program as well as the cost of living, and at the same time recognizing the importance of avoiding price impediments to the supply of essential military items, OPS sought to follow the general policy of setting ceilings on the defense procurement items of an essentially civilian or commercial nature, such as food and clothing, and exempting exclusively military end items and their exclusively military components and parts.

SR I, issued only a few days after the GCPR itself, contained a list of exempted commodities and services based on what was necessarily a very hasty review of the range of military procurement. Many of the exempt items listed were clearly recognizable as strictly combat items procured solely by defense agencies. In view of the fact that this list was gotten together so quickly, it is not strange that doubt might exist as to the necessity for the exemption of some of the listed items, such as canteens or identification tags. Nevertheless, there was a natural tendency for items originally exempt when sold on defense contracts to continue to be so exempt. Especially in view of the increasing emphasis on decontrol in the later days of OPS, it would have been contrary to the general stream of actions to attempt to reinstitute price controls on items already exempt.

Thus, when a revised general overriding regulation was issued in 1952 , bringing together a number of provisions relating to purchases by federal agencies, at which time SR I was revoked, the exemptions from the GCPR contained in SR $x$ were in general continued in the new regulation. ${ }^{125}$

Some changes affecting these exemptions were made, however. Thus, the definition of "Defense Agency" was expanded to include, in addition to agencies listed in SR I, the Emergency Procurement Service of GSA, the Defense Materials Procurement Agency, and any official agency of a foreign government.

SR I also exempted sales by the Atomic Energy Commission, sales of scrap, waste, damaged or used materials by a defense agency, and sales by the Department of Defense through its commissaries, exchanges, and stores.

These exemptions, like the others in SR r, were from the GCPR only. The commodities or transactions previously exempt under SR I became subject to price control, in the absence of further exemption, as other specific regulations were issued. Thus, sales of iron and steel scrap by defense agencies were exempt so long as the GCPR covered them, but they became subject to ceilings when a specific tailored regulation was issued. ${ }^{126}$

125 GOR 2, Revision I, I7 FED. REG. 6733 (1952).

${ }^{120} \mathrm{CPR}$ 5, Iron and Steel Scrap, I6 FED. REg. I06I (195I). 
Similarly, sales by Defense Department commissaries, exchanges, and stores were exempt only to the extent that they were not brought under other specific ceiling price regulations. However, sales by Defense Department commissaries and exchanges were exempted from all price regulations in $1953 .{ }^{127}$ Sales by the Veterans Canteen Service, which maintained facilities in the hospitals and homes of the Veterans Administration, were also exempt. ${ }^{128}$

The freeze technique was not as appropriate for federal agencies as for commercial or industrial concerns, and in particular it was not appropriate for sales of used and surplus goods bought for use rather than resale. For these reasons, pending further study looking to a possible specific regulation for sales by federal agencies, an exemption from the GCPR was authorized for sales of United States Government property not acquired or produced for sale or stockpile and not covered by another supplementary regulation or ceiling price regulation. ${ }^{129}$ Although originally intended to be temporary, the exemption was eventually continued indefinitely. ${ }^{\mathbf{1 3 0}}$ Like the general GCPR exemption for used items, the exemption was limited to the GCPR, and was not applicable where a particular problem was already covered by a specific regulation, nor was it applicable to resale by dealers.

It has been previously noted that in the last half of I95I, a large number of sales of services by federal, state.or local governmental agencies were exempted from price control. ${ }^{131}$ In 1952, certain types of sales of commodities by federal agencies were also exempted. Included were:

I. Sales of commodities by a federal agency to other federal agencies for use and not for resale. In these cases the Federal Government was both buyer and seller.

2. Sales by a federal agency to any foreign government or official agency thereof. These transactions were often made in connection with the carrying out of the national foreign policy, and price was usually a secondary factor.

3. Sales by a federal agency to a relief organization for export or donation. These sales presented little or no inflationary dangers; price here also was usually secondary. ${ }^{132}$

Following the amendment to the Defense Production Act in 1952 prohibiting ceilings on commodities and services supplied by state or local governments, sales of commodities by these government units were exempted. ${ }^{133}$ The previous exemption of services supplied by government agencies was continued. No over-all exemption of commodities sold by the Federal Government was issued, however, because federal agencies in some fields represented most important sources of supply, as in the case of iron and steel scrap.

An earlier exemption applied to sales by the United States to federal agencies and

127 Amendment I to GOR II, Revision 2, I8 FED. REg. 227 (I953).

${ }^{128}$ GOR $x$ I, I6 FED. REG. 4618 (I95I).

${ }^{120}$ SR 72 to GCPR, I6 FED. REg. IOI59 (195I).

${ }^{130}$ Extended by Amendment $I$, I7 FED. REG. 67 (195I), continued indefinitely by Amendment 2 , 17 Fed. Reg. I883 (1952). Revision I, 18 FEd. REG. 626 (1953), made the exemption for federal agencies somewhat broader than the general exemption from the GCPR for used supplies.

131 Amendment 2, GOR 14, I6 FED. REg. 9563 (I95I).

102 GOR II, Revision I, I7 FED. REG. 6I5I (1952).

${ }^{133}$ Sec. Iog(c), 66 Stat. 299 (1952); GOR II, Revision 2, I7 Fed. Reg. 6702 (I952). 
by the District of Columbia to its own and federal agencies, of commodities produced and services supplied by their respective penal institutions. ${ }^{134}$ These transactions, in so far as the Federal Government was concerned, were largely covered by the subsequent general exemption of sales of commodities by one federal agency to another. Sales by District of Columbia agencies were included in the 1952 general statutory exemption of sales by state and local governments.

\section{Place of Exemptions in a General Freeze}

The concept of a general freeze as an across-the-board ceiling on all prices, if applied literally and rigidly, would rule out any provisions for exemptions. Yet, the GMPR, issued by OPA in 1942, as well as the GCPR, issued by OPS in I95I, both popularly described as general freezes, were subject to significant exemptions and exceptions.

Some of the exemptions, of course, were required by the mandatory terms of the basic statutory authority to impose ceilings. Others, however, were the result of the exercise of administrative discretion, under the general authority, contained in both the Emergency Price Control Act of 1942 and the Defense Production Act of 1950 , to provide exemptions where necessary or proper to effectuate the purposes of the legislation. ${ }^{135}$

There would seem to be little question but that authority to make exemptions is necessary and desirable in a continuing controls program, even under a general freeze. Past experience under OPS and OPA confirms this, although it also points up the fact that a too free and liberal legislative or administrative exemption policy may impair the effectiveness of a direct controls program.

Undoubtedly, in any future full scale economic controls legislation, as contrasted with temporary freeze action, Congress would see fit, as it has in the past, to specify mandatory exemptions and to provide standards for discretionary exemptions.

At the same time, however, it must be recognized that there was a feeling that a general freeze, to be most effective, should be as all encompassing and as inflexible as possible. This poses the dilemma which made price control administrators envy tight-rope acrobats. If a general freeze, to be completely effective, is inflexible and without exceptions, it may be too tight, creating inequities as well as obstacles to essential defense production. On the other hand, if substantial exceptions are made, the freeze becomes loose and ineffective.

A middle course between the horns of this dilemma would be to recognize that some exemptions are necessary or desirable, but to hold these to a minimum in the initial period of a general freeze whose purpose is to stop widespread movement of prices. The major categories of initial exemptions from a general freeze might be summarized as follows:

First, of course, would be the exemptions required by the basic legislative authority.

${ }^{134}$ GOR I9, I6 FED. REG. 10260 (195r).

${ }^{135}$ Sec. 2(c), Emergency Price Control Act of 1942, 56 StAT. 23 (x942), as amended, 5o U. S. C. App. $\$ 902(c)$ (1946); Sec. 402(f), Defense Production Act of 1950, 64 STAT. 803, as amended, 50 U. S. C. App. \$2102(f) (Supp. 1952). 
Notwithstanding the view that exemptions impair the effectiveness of a general freeze of prices, it is significant that both under OPA and OPS substantial exemptions from price control were required by specific statutory provisions enacted by Congress.

Second would be the areas where rigid application of a freeze might interfere with military needs or the defense program. For example, both OPA and OPS followed the practice of exempting strictly military items.

Third would be those commodities, services, or transactions, which would be administratively most difficult to control, and which would not be important enough to the costs of the defense program or to the cost of living to create serious difficulties if left free from controls.

While a recitation of the items exempt from the GCPR seems long and to cover a multitude of things, this is largely a result of the original decision to cover everything not specifically included. If any attempt were made to list in the same detail all the things covered by the freeze, the exemption list would be quickly reduced to its true and relatively less important size. 